\title{
IMPACT OF MARBLE MINING ON SOIL PROPERTIES IN A PART OF GUINEA SAVANNA ZONE OF SOUTHWESTERN NIGERIA
}

Adewole M. B.* and Adesina M. A.

http://dx.doi.org/10.4314/ejesm.v4i2.1

\begin{abstract}
The effects of marble mining activities on the properties of soils of Igbeti marble area, Oke-Ogun, Southwestern Nigeria were investigated. Sample plots of $10 \times 10 \mathrm{~m}^{2}$ were established at $150 \mathrm{~m}$ intervals from the factory site up to a distance of $600 \mathrm{~m}$ and with a sample plot at $10 \mathrm{~km}$ to serve as control in four cardinal directions. A total of 84 composite soil samples from 21 established plots were taken for soil physico-chemical properties. No plot falls under agricultural crops. The results show that there is drastic deterioration in the quality of soil as a result of mining activities. There was increase in total porosity and decrease in bulk density of the soil as you move away from the mining site. The soil $\mathrm{pH}$ changed greatly from 5.90 in the control site to 8.20 in highly polluted soils. Soil organic matter, total nitrogen and available phosphorus decreased with increase in dust particulate from the mining sites. Except for $\mathrm{Ca}^{2+}$ and $\mathrm{Mg}^{2+}$ that decreased with distance from the mining site, $\mathrm{Na}^{+}$and $\mathrm{K}^{+}$increased slightly. The availability of the extractable micronutrients $\left(\mathrm{Fe}^{2+}, \mathrm{Mn}^{2+}, \mathrm{Cu}^{2+}\right.$ and $\left.\mathrm{Zn}^{2+}\right)$ increased as the soil acidity increased, though $\mathrm{Cu}^{2+}$ availability dropped slightly at control site. It is concluded that there is the need for close monitoring of marble mining activities in Nigeria as deposit of marble particulates may result to soil nutrients' imbalance and hence poor soil health especially in areas polluted with marble particulates.
\end{abstract}

Key words: Mine waste, pollution monitoring, soil deterioration, soil pollution, soil nutrients' imbalance.

\section{Introduction}

Marble is one of the solid minerals present in abundance in Nigeria (Godwin, 2006). Igbeti, a semi-urban town in Oke-Ogun Area, Oyo State, Nigeria has a large deposit of marble. Previous studies on Igbeti marble found $\mathrm{CaCO}_{3}$ (44.26 $67.26 \%)$ and $\mathrm{MgCO}_{3}(37.80-45.60 \%)$ as major constituents (Emefurieta and Ekuajemi, 1995) and with radioactive materials at acceptable concentrations, thus making its usage save in building constructions (Ademola et al., 2008). Marble is formed from limestone as a result of heat and pressure in the earth crust thereby causing a change in texture and makeup of the limestone.

Institute of Ecology and Environmental Studies,

Obafemi Awolowo University, Ile-Ife, Nigeria.

*Corresponding author. E-mail: adewoledele2005@yahoo.co.uk
This process is called recrystallization. Marble mining is part of industrialization while also providing employment for hundreds of people within the community. However, as marble mining progresses, the destruction of ecosystem continues, which resulted in soil deterioration. Dust particulate due to marble mining is a major environmental contamination in Igbeti area (Ademola et al., 2008). The particulates that spread to surrounding areas have led to considerable accumulation of $\mathrm{Ca}$ and Mg compounds in the soils, sediments, 
water and vegetation. Calcium and Magnesium occur in soil and plant as divalent cations, $\mathrm{Ca}^{2+}$ and $\mathrm{Mg}^{2+}$ respectively. Mining is one of the important pathways by which soils are polluted (Ademoroti, 1996). Mining has considerable effect on the air and water, loss of biodiversity, soil pollution and land degradation (Kumar, 1996). Mining also results to clearing of vegetation, reduces essential nutrients and organic matter of the soil, reduces biological activity and decreases productivity of the soil (Pandey and Kumar, 1996). Mineral exploration directly or indirectly affects both the living things and non-livings things through the physical and chemical modification of the soil environment (Ratcliffe, 1974). Excess of Ca usually results in low solubility of $\mathrm{P}, \mathrm{Fe}, \mathrm{Mn}, \mathrm{B}$ and $\mathrm{Zn}$ (Pandey et al., 2005). Ca has ability to capture $\mathrm{P}$ to form Calcium triphosphate, thus rendering $\mathrm{P}$ unavailable to plants (Dutta and Agrawal, 2002). The abundance of $\mathrm{Ca}$ in the marble dust decreases the availability of other nutrients, especially nitrogen (Demooy and Pesek, 1996). $\mathrm{Ca}^{2+}$ and $\mathrm{Mg}^{2+}$ are chemically similar (Pandey et al., 2005). Nitrogen is one of the major soil nutrients for good growth and yield of crops. All these, therefore may cause low productivity of crops in the areas affected by marble particulates. Traffic on the top soil during marble blasting and evacuation may also lead to soil compaction. Heaps of excavated marble are sometimes abandoned in many locations for months before they are transported for industrial use. Maize, sorghum, cowpea, cassava and yam are major crops cultivated by farmers in Igbeti and the surrounding villages (Rahji, 2005) on the soils that have been inadvertently altered as a result of mining activities.

Since the commencement of marble mining in the early 1960s in the marble deposits of Igbeti, Oke-Ogun area of Oyo State, Nigeria, no detailed study of the possible impact of marble particulates on the physicochemical properties of soils of the area has been studied. Most Nigerian farmers practice subsistence farming (Salahu and Dauda, 2005) and the Igbeti farmers, with those from the surrounding villages are no exceptions where farming is done within short distances from their homes and mostly within already degraded farmland. In this paper, we report on the effects of marble mining on soil physicochemical properties as well as its impact on soil nutrients availability in one of the major marble deposits in Nigeria.

\section{Materials and Methods}

\section{Study site, sample collection and preparation}

The study area is located in Igbeti and lies within latitude $8^{\circ} 40^{\prime}$ and $9^{\circ} 05^{\prime} \mathrm{N}$ longitude $3^{\circ}$ $45^{\prime}$ and $4^{\circ} 15^{\prime} \mathrm{E}$ in Olorunsogo Local Government Area of Oyo State. It falls within the Northern Guinea savanna of southwestern Nigeria (LRS, 1976). The rainfall pattern is bimodal and falls from late February to late October each year.

Soil samples were collected randomly using Dutch soil auger from $10 \times 10 \mathrm{~m}^{2}$ established plots covering a distance of $600 \mathrm{~m}$ at $150 \mathrm{~m}$ interval from the mining site and also at 10,000 $m$ away, where the impact of marble particulates was considered to be low in the four cardinal directions. Fifteen core samples, randomly taken to the depth, $0-15 \mathrm{~cm}$ from each sampling plot formed a composite soil sample. Four composite soil samples were collected from each of 21 established plots to give a total of 84 composite samples for laboratory analysis. All the established plots fell within opened-up areas due to mining and undisturbed areas with native vegetation, depending on the distance. No plot falls under agricultural crops. The soil samples were airdried for 7 days and sieved using $2 \mathrm{~mm}$ sieve. The two marble lumps from the mining were ground and also sieved using $2 \mathrm{~mm}$ sieve for its major constituents determination.

\section{Laboratory analyses}

The particle size analysis was determined using hydrometer method in $5 \%$ sodium hexametaphosphate as the dispersing agent (Bouyoucos, 1951). 
Total porosity, bulk density and soil moisture content were determined using methods outlined by Odu et al. (1986). The $\mathrm{pH}$ of the soil was determined electrometrically using a $\mathrm{pH}$ meter in $1: 1$ soil $-1 \mathrm{M}$ $\mathrm{KCl}$ and 1:1 soil-water suspensions (Mclean, 1982). Organic matter was determined using Walkley Black wet oxidation method (Nelson and Sommers, 1982). Total nitrogen of the soil was determined using the macro Kjeldahl method (Bremner and Mulvaney, 1982). Available phosphorus in the soil was determined using Bray $\mathrm{P}_{1}$ method (Olsen and Sommers, 1982).

Exchangeable cations $\left(\mathrm{Ca}^{2+}, \mathrm{Mg}^{2+}, \mathrm{K}^{+}\right.$and $\left.\mathrm{Na}^{+}\right)$ were determined using $1 \mathrm{M} \mathrm{NH} \mathrm{NHAc}_{4} \mathrm{OAmmonium}$ acetate) buffered at $\mathrm{pH} 7.0$ as extractant (Thomas, 1982). The $\mathrm{K}^{+}$and $\mathrm{Na}^{+}$concentrations in soil extracts were read on Gallenkamp flame photometer while $\mathrm{Ca}^{2+}$ and $\mathrm{Mg}^{2+}$ concentrations in soil extracts were read using Perkin-Elmer Model 403 atomic absorption spectrophotometer (AAS). The exchangeable acidity $\left(\mathrm{H}^{+}+\mathrm{Al}^{3+}\right)$ in the soil was extracted with $1 \mathrm{M} \mathrm{KCl}$ (Thomas, 1982). Solution of the extract was titrated with $0.05 \mathrm{M} \mathrm{NaOH}$ to a permanent pink endpoint using phenolphthalein as indicator. The amount of base $(\mathrm{NaOH})$ used is equivalent to the total amount of exchangeable acidity $\left(\mathrm{H}^{+}+\mathrm{Al}^{3+}\right)$ in the aliquot taken (Odu et al., 1986).

The total sum of exchangeable bases $\left(\mathrm{Ca}^{2+}+\mathrm{Mg}^{2+}+\mathrm{K}^{+}+\mathrm{Na}^{+}\right)$and total exchangeable acidity $\left(\mathrm{H}^{+}+\mathrm{Al}^{3+}\right)$ gave the effective cation exchangeable capacity (ECEC) (Juo, 1979).

i.e. $\mathrm{ECEC}=\mathrm{Ca}^{2+}+\mathrm{Mg}^{2+}+\mathrm{K}^{+}+\mathrm{Na}^{+}+\mathrm{H}^{+}+\mathrm{Al}^{3+}$

Percentage base saturation was calculated as the ratio between the sum of exchangeable bases and effective cation exchangeable capacity multiplied by 100 .

i.e. Base Saturation $=\frac{\mathrm{Ca}^{2+}+\mathrm{Mg}^{2+}+\mathrm{K}^{+}+\mathrm{Na}^{+}}{\mathrm{ECEC}} \times 100$

The micronutrients ( $\mathrm{Zn}, \mathrm{Mn}, \mathrm{Fe}$ and $\mathrm{Cu}$ ) were extracted with $0.1 \mathrm{M} \mathrm{HCl}$ (Juo, 1982) and their concentrations in soil extracts were read on AAS (Perkin-Elmer Model 403).

The data from soil analyses of the sampled plots were subjected to descriptive and one-way analyses of variance.

\section{Results and Discussion Soil physical properties}

The results of the physical properties of the soils from different sampling sites are presented in Table 1 . The soil texture was sandy loam in all the sites except at $450 \mathrm{~m}$ away from the mining site that was loamy sand. This is normal for this type of humid tropical soils that are mostly sandy in nature (Lal, 1985). The total porosity of the soils ranged from $38.23 \pm 0.87$ $\%$ in the mining area to $72.56 \pm 1.14 \%$ at $10,000 \mathrm{~m}$ away from the mining area. This gradual increase of total porosity as we move away from the mining site can be attributed to the top soil disturbance caused by the thin layer of marble particulates (Ibanga et al., 2005). Moisture content of the soils decreased as we moved away from the mining site. The inverse relationships between total porosity and moisture content have been extensively discussed by many scientists. Aina (1989) found a significant reduction in total porosity of forest fallow (58\%) of an alfisol soil to when the soil was being disturbed (42\%) which was inversely related to soil moisture content. Lal (1985) however, obtained increased soil moisture content and total porosity under forest re-growth in teak plantation to an opened-up land which was attributed to the canopy cover by the trees. The bulk density of the soil at the mining area was $1.68 \pm 0.12 \mathrm{mg} \mathrm{m}^{-3}$ and decreased progressively to $1.05 \pm 0.15 \mathrm{mg} \mathrm{m}^{-3}, 10,000 \mathrm{~m}$ away. Heavy traffic on the top soil within the vicinity of the mining may have contributed to the high bulk density within the mining area (Aina, 1989).

\section{Soil chemical properties}

The chemical properties of the marble soils are shown in Table 2. The $\mathrm{pH}$ of the soil (in 1: 1 soil $-1 \mathrm{M} \mathrm{KCl}$ ) ranged from $8.20 \pm 0.20$ within the marble mining to $5.90 \pm 0.10,10 \mathrm{~km}$ away from the mining site. The indication was, the soils varied from slightly alkaline to slightly acidic condition. African soils are generally slightly acidic (Akinnifesi et al., 2005) if uncontaminated and the slight alkalinity of soils within the marble mining was as a result of accumulation of marble particulates on the top soil. 


\section{Table 1: Physical properties of the marble soils}

Sampling distance (away from the mining site, in metre)

Property

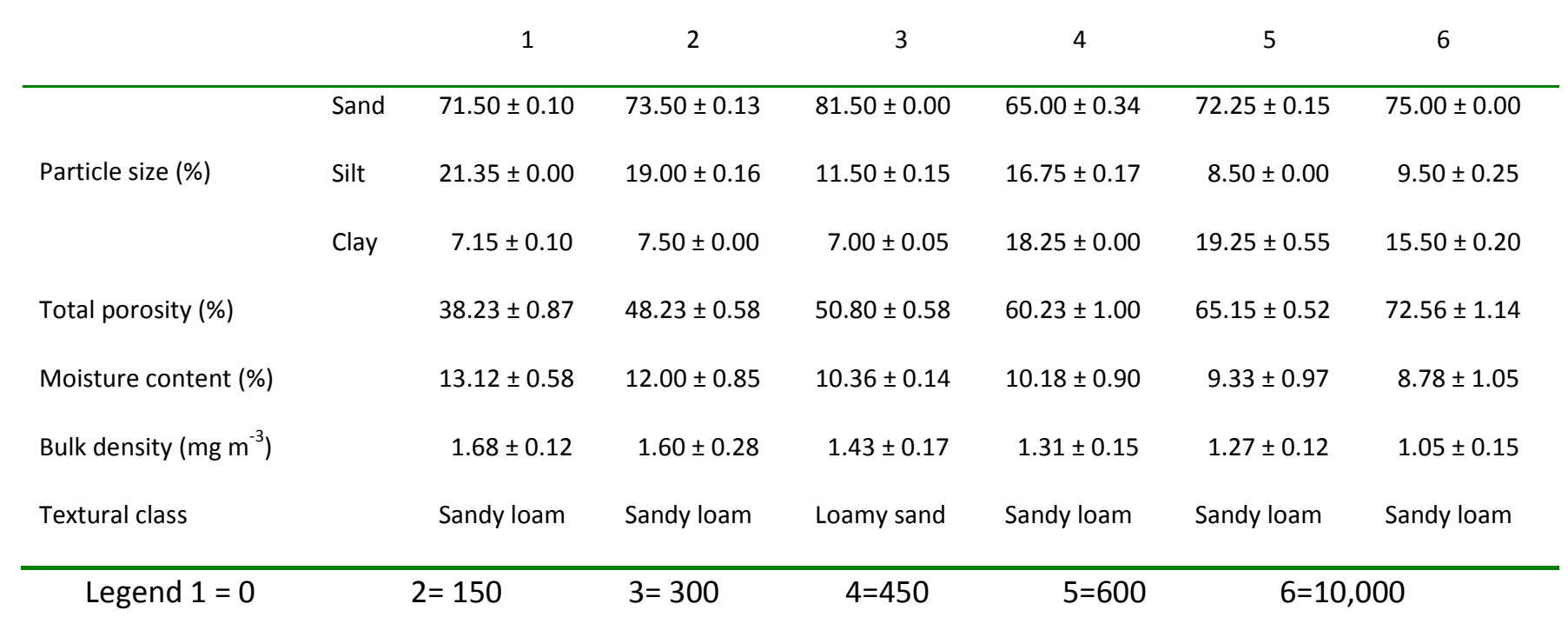

The carbonate ions, $\mathrm{CO}_{3}{ }^{2-}$ present in Igbeti marble must have contributed to the soil slight alkalinity (Audu and Mohammad, 2007) within 0 - $450 \mathrm{~m}$ marble area.

The soil organic carbon increased with increase in distance from the mining area. The lowest value, $3.10 \pm$ $0.06 \mathrm{~g} \mathrm{~kg}^{-1}$ in the mining area increased progressively to $10.22 \pm 0.08 \mathrm{~g} \mathrm{~kg}^{-1}, 10,000 \mathrm{~m}$ away were obtained. This can be attributed to the removal of the vegetation and top soil in the mining area and the immediate surroundings to pave way for the mining activities. The removal of vegetation (Salami et al., 2002) and top soil (Agboola, 1982) had been found to have adverse effect on humid tropics' soil organic matter. Also, total nitrogen increased from $0.30 \pm 0.08$ to $1.13 \pm 0.08 \mathrm{~g} \mathrm{~kg}^{-}$ ${ }^{1}$ progressively as organic carbon content increased. This may be attributed to the fact that available soil nitrates of the tropical African soils are organic carbon dependent (Agboola, 1982).

Available phosphorus contents of the soils increased from $\left(\mathrm{mg} \mathrm{kg}^{-1}\right) 9.26 \pm 0.03$ to $52.74 \pm 0.06$ as we move away from the mining site. This may be due to decrease in base saturation of the soils (from $99.45 \pm$ 0.07 to $81.48 \pm 0.04 \%$ ) as the alkalinity nature may encourage phosphorus fixation or immobilization (Wild, 1995); or capture by $\mathrm{Ca}$ to form calcium triphosphate, one of the unavailable forms of phosphorus.
The exchangeable acidity, $\mathrm{Al}^{3+}+\mathrm{H}^{+}$, increased from $\left(\mathrm{mg} \mathrm{kg}^{-1}\right) 0.30 \pm 0.10$ to $0.65 \pm 0.05$ as the soil $\mathrm{pH}$ values decreased. However, exchangeable bases $\left(\mathrm{Na}^{+}, \mathrm{Ca}^{2+}\right.$ and $\left.\mathrm{Mg}^{2+}\right)$ decreased progressively, while $\mathrm{K}^{+}$values followed no definite pattern with increase in distance from the marble mining site. $\mathrm{Ca}^{2+}$ and $\mathrm{Mg}^{2+}$ are the two constituents of Igbeti marble and these are deposited with mine dust which decreased with increase in distance. $\mathrm{K}^{+}$variability may be the result of the humid tropics soil micro-variability. The general increase in concentration levels of the ECEC and base saturation may have been influenced by increase in soil acidity as shown in Figures 1 and 2.

The extractable micronutrients $\left(\mathrm{Fe}^{2+}, \mathrm{Mn}^{2+}\right.$, $\mathrm{Cu}^{+2}$ and $\left.\mathrm{Zn}^{2+}\right)$ increased from $\left(\mathrm{mg} \mathrm{kg}^{-1}\right) \mathrm{Fe}^{2+} 10.44$ \pm 1.45 to $41.87 \pm 0.03, \mathrm{Mn}^{2+} 4.37 \pm 0.03$ to 38.23 $\pm 0.10, \mathrm{Cu}^{2+} 0.90 \pm 0.06$ to $1.46 \pm 0.15$ and $\mathrm{Zn}^{2+}$ $0.14 \pm 0.06$ to $0.94 \pm 0.06$ with increase in soil acidity and distance. This trend also agreed with the statement of Wild (1995) that the solubility and mobility of metals in soil increase as soil acidity increases. 
Impact of Marble Mining on soil......... Adewole and Adesina EJESMVol. 4 No.2 2011

Table 2: Chemical properties of the marble soils*

Sampling distance (away from the mining site, in metre)

Property

\begin{tabular}{|c|c|c|c|c|c|c|c|}
\hline & & 1 & 2 & 3 & 4 & 5 & 6 \\
\hline & in $\mathrm{H}_{2} \mathrm{O}$ & $8.70 \pm 0.20$ & $7.80 \pm 0.30$ & $7.70 \pm 0.20$ & $7.50 \pm 0.20$ & $6.20 \pm 0.20$ & $5.90 \pm 0.10$ \\
\hline $\mathrm{Ph}$ & in $1 \mathrm{M} \mathrm{KCl}$ & $8.30 \pm 0.20$ & $7.50 \pm 0.20$ & $7.30 \pm 0.30$ & $6.90 \pm 0.20$ & $5.60 \pm 0.10$ & $5.40 \pm 0.20$ \\
\hline Organic carbon $\left(\mathrm{g} \mathrm{kg}^{-1}\right)$ & & $3.10 \pm 0.06$ & $3.10 \pm 0.00$ & $3.90 \pm 0.10$ & $4.97 \pm 0.05$ & $8.12 \pm 0.05$ & $10.22 \pm 0.08$ \\
\hline Total nitrogen $\left(\mathrm{g} \mathrm{kg}^{-1}\right)$ & & $0.30 \pm 0.08$ & $0.33 \pm 0.05$ & $0.40 \pm 0.05$ & $0.46 \pm 0.10$ & $0.85 \pm 0.05$ & $1.13 \pm 0.08$ \\
\hline Available $\mathrm{P}\left(\mathrm{mg} \mathrm{kg}^{-1}\right)$ & & $9.26 \pm 0.03$ & $9.26 \pm 0.05$ & $9.53 \pm 0.05$ & $12.17 \pm 0.10$ & $18.10 \pm 0.07$ & $52.74 \pm 0.06$ \\
\hline Exchangeable acidity & $\mathrm{Al}^{3+}$ & $0.20 \pm 0.00$ & $0.20 \pm 0.00$ & $0.20 \pm 0.05$ & $0.30 \pm 0.05$ & $0.30 \pm 0.00$ & $0.30 \pm 0.05$ \\
\hline$\left(\mathrm{cmol} \mathrm{kg}^{-1}\right)$ & $\mathrm{H}^{+}$ & $0.10 \pm 0.00$ & $0.10 \pm 0.00$ & $0.24 \pm 0.03$ & $0.20 \pm 0.05$ & $0.25 \pm 0.00$ & $0.35 \pm 0.00$ \\
\hline Exchangeable cation & $\mathrm{Na}^{+}$ & $0.38 \pm 0.02$ & $0.26 \pm 0.02$ & $0.22 \pm 0.05$ & $0.15 \pm 0.00$ & $0.15 \pm 0.00$ & $0.12 \pm 0.02$ \\
\hline \multirow[t]{3}{*}{$\left(\mathrm{cmol} \mathrm{kg}^{-1}\right)$} & $\mathrm{K}^{+}$ & $0.11 \pm 0.01$ & $0.16 \pm 0.01$ & $0.13 \pm 0.00$ & $0.18 \pm 0.05$ & $0.17 \pm 0.05$ & $0.27 \pm 0.05$ \\
\hline & $\mathrm{Ca}^{2+}$ & $46.05 \pm 1.05$ & $19.86 \pm 1.14$ & $11.80 \pm 0.20$ & $10.12 \pm 0.08$ & $1.56 \pm 0.10$ & $1.53 \pm 0.07$ \\
\hline & $\mathrm{Mg}^{2+}$ & $5.66 \pm 0.25$ & $5.02 \pm 0.16$ & $1.65 \pm 0.02$ & $1.05 \pm 0.03$ & $1.05 \pm 0.05$ & $0.94 \pm 0.05$ \\
\hline \multirow{2}{*}{$\begin{array}{l}\text { Extractable } \\
\text { micronutrients }\end{array}$} & $\mathrm{Fe}^{2+}$ & $10.44 \pm 1.45$ & $10.44 \pm 1.06$ & $15.92 \pm 0.88$ & $22.98 \pm 0.65$ & $27.58 \pm 0.52$ & $41.87 \pm 0.03$ \\
\hline & $\mathrm{Mn}^{2+}$ & $4.37 \pm 0.03$ & $7.12 \pm 0.06$ & $8.58 \pm 0.06$ & $13.03 \pm 0.00$ & $14.29 \pm 0.10$ & $38.23 \pm 0.10$ \\
\hline \multirow{2}{*}{$\left(\mathrm{mg} \mathrm{kg}^{-1}\right)$} & $\mathrm{Cu}^{2+}$ & $0.90 \pm 0.06$ & $1.70 \pm 0.05$ & $1.52 \pm 0.08$ & $1.61 \pm 0.10$ & $1.80 \pm 0.10$ & $1.46 \pm 0.15$ \\
\hline & $\mathrm{Zn}^{2+}$ & $0.14 \pm 0.06$ & $0.20 \pm 0.03$ & $0.20 \pm 0.03$ & $0.26 \pm 0.06$ & $0.31 \pm 0.05$ & $0.94 \pm 0.06$ \\
\hline $\operatorname{CEC}\left(\mathrm{cmol} \mathrm{kg}^{-1}\right)$ & & $52.09 \pm 0.33$ & $25.30 \pm 0.00$ & $13.80 \pm 0.09$ & $11.50 \pm 0.05$ & $2.93 \pm 0.07$ & $2.86 \pm 0.05$ \\
\hline $\operatorname{ECEC}\left(\mathrm{cmol} \mathrm{kg}^{-1}\right)$ & & $52.39 \pm 0.33$ & $25.60 \pm 0.33$ & $14.24 \pm 0.07$ & $12.00 \pm 0.05$ & $3.48 \pm 0.07$ & $3.51 \pm 0.05$ \\
\hline Base saturation (\%) & & $99.43 \pm 0.02$ & $98.83 \pm 0.06$ & $96.91 \pm 1.00$ & $95.83 \pm 0.00$ & $84.20 \pm 0.07$ & $81.48 \pm 0.04$ \\
\hline
\end{tabular}

* Marble lump contained (i) $\mathrm{Ca}^{2+}=47.50 \mathrm{cmol} \mathrm{kg}^{-1}$; (ii) $\mathrm{Mg}^{2+}=55.94 \mathrm{cmol} \mathrm{kg}^{-1}$

Legend $1=0 \quad 2=150 \quad 3=300 \quad 4=450 \quad 5=600 \quad 6=10,000$ 


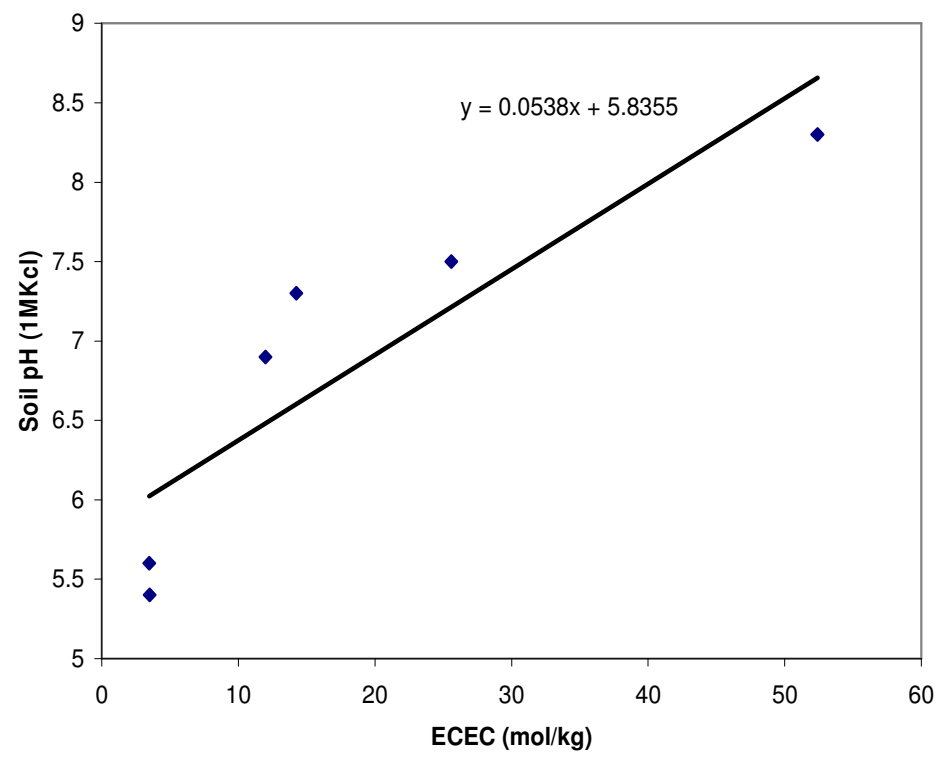

Figure 1: Regression plot for the soil pH against the ECEC of Igbeti marble soils

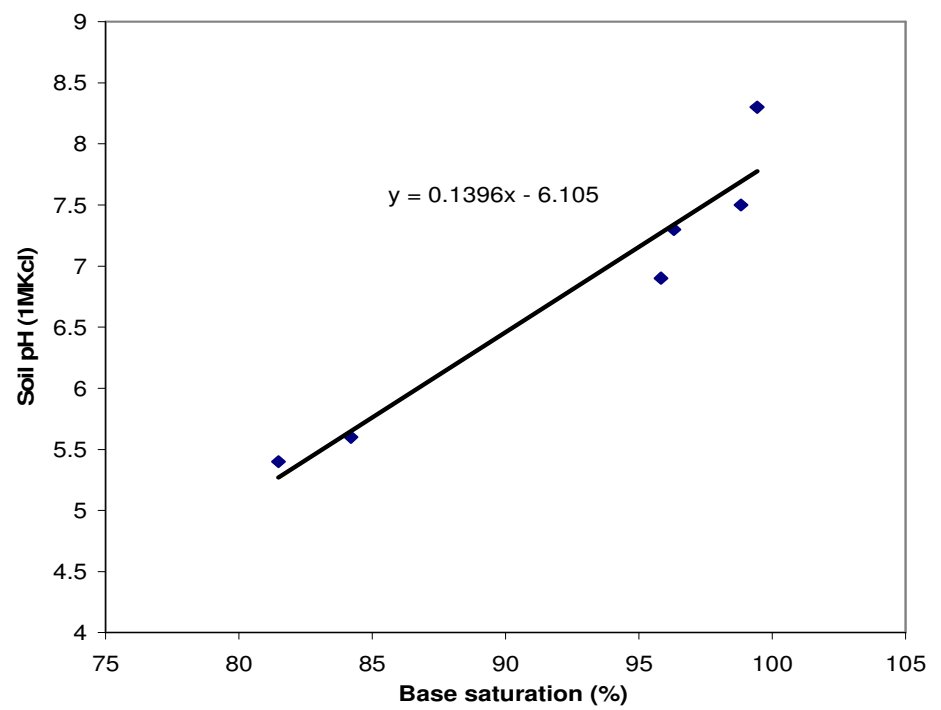

Figure 2: Regression plot for the soil $\mathrm{pH}$ against the percentage base saturation of Igbeti marble soils.

\section{Conclusion}

Particulates from marble mining have degradable effect on soil physicochemical properties and these are added burden to microvariability of soil properties of the study area. Nitrogen and phosphorus; two of the major plant nutrients reduced in concentrations within the mining areas and these increased in concentrations with distance, away from the mining areas. The organic carbon that the CEC depend on also reduced within the mining areas.
The organic carbon that the CEC depend on also reduced within the mining areas. All these may lead to low crop yield due to marble particulates that get deposited on soil and vegetation of the area. Apart from the soil health that would be in danger due to soil-nutrient imbalance that may set in as a result of marble particulates, the income of the subsistence farmers in the study area may be adversely affected also due to reduced crop yield they may experience. 


\section{References}

Ademola, A.K., Hammed, O.S. and Adejumobi, C.A. (2008), Radioactivity and dose assessment of marble samples from Igbeti mines, Nigeria. Radiation protection dosimetry, 132(1), 94-99.

Ademoroti, C.M.A. (1996), Environmental Chemistry and Toxicology. Foludex Press Ltd., Ibadan. Nigeria. 215pp.

Agboola, A.A. (1982), Soil testing, soil fertilizer and fertilizer use in Nigeria. A paper presented at the First National Seminar in Agricultural Land Resources held at Kaduna.

Aina, P.O. (1989), Soil erosion problems in Nigeria: Issues and perspectives of soil management for conservation. A paper presented at the $17^{\text {th }}$ annual conference of the Soil Science Society of Nigeria, Nsukka, Nigeria.

Akinnifesi, T.A., Asubiojo, O.I. and Amusan, A.A. (2005), Effects of fungicide residues on the physico-chemical characteristics of soils of a major cocoa-producing area of Nigeria. Science of the Total Environment, 366, 876-879.

Audu, A.A. and Muhammad, A.A. (2007), Analysis of limestone samples sourced from the middle belt zone of Nigeria. International Journal of Pure and Applied Sciences, 1(2), 1-8.

Bouyoucos, C.J. (1951), A recalibration of the hydrometer method for making the mechanical analysis of soils. Agronomy Journal, 43, 434438.

Bremner, J.M. and Mulvaney, C.S. (1982), Nitrogen-Total. In: Methods of soil analysis. 2nd ed., Part 2 ed., A. L. Page, R. H. Miller, and D. R. Keeney. eds. pp 595-624. Agronomy Monograph No. 9. Madison, WI: American Society of Agronomy.
Demooy, C. J. and Pesek, J. (1996), Nodulation response of soabeans to added Phosphorus, Potassium and Calcium salts. Agronomy Journal 58, 275-280.

Dutta, R. K. and Agrawal, M. (2002), Effect of tree plantations on the soil characteristics and microbial activity of coalmine spoil land. Tropical Ecology 43(2), 313-324.

Emefurieta, W.O. and Ekuajemi, V.O. (1995), Lime products and economic aspects of Igbeti, Ososo and Jakuta deposits in Southwestern Nigeria. Journal of Mining and Geology. 31(1), 78-89.

Godwin, A. (2006), How the solid minerals sector fared. Punch (Nigeria) limited, Ikeja, Lagos, Nigeria. pp 22.

Ibanga, I.J., Udoma, G.H., Edet, A.B. and Akpan, F.S. (2005), Physico-chemical properties of some limestone soils in Southeastern Nigeria. Nigerian Journal of Soil Science. 15: 81-86.

Juo, A.S.R. (1979), Selected methods for soil and plant analysis. Published by International Institute of Tropical Agriculture (IITA), Ibadan, Nigeria. 70 pp.

Juo, A.S.R. (1982), Automated and semi-automated methods for soil and plant analysis. Published by International Institute of Tropical Agriculture (IITA), Ibadan, Nigeria. 33 pp.

Lal R. (1985), Mechanical tillage system effects on properties of a tropical alfisol in watersheds cropped to maize. Soil and tillage research, 6, 149-161.

LRS (Land Resource Study). (1976), Soils of the Western State Savanna in Nigeria. Volume 1. The Environment. Land Resources Division, Ministry of Overseas Development, Tolworth Tower, England. $185 \mathrm{pp}$. 
Mclean, E.O. (1982), Soil pH and lime requirement. In Methods of Soil Analysis. 2nd ed., Part 2 ed., A. L. Page, R. H. Miller, and D. R. Keeney. eds. pp 595624. Agronomy Monograph No. 9. Madison, WI: American Society of Agronomy.

Nelson, D.W. and Sommers, L.E. (1982), Total carbon, organic carbon and organic matter. In: Methods of soil analysis. 2nd ed., Part 2 ed., A. L. Page, R. H. Miller, and D. R. Keeney. eds. pp 539579. Agronomy Monograph No. 9. Madison, WI: American Society of Agronomy.

Odu, C.T.I., Babalola, O, Udo, E.J., Ogunkunle, A.O., Bakare, T.A.and Adeoye, G.O. (1986), Laboratory manual for agronomic studies in soil, plant and microbiology. $1^{\text {st }}$ edition. Published by the Department of Agronomy, University of Ibadan, Ibadan, Nigeria. $83 \mathrm{pp}$.

Olsen, S.R. and Sommers, L.S. (1982), Phosphorus. In Methods of Soil Analysis. 2nd ed., Part 2 ed., A. L. Page, R. H. Miller, and D. R. Keeney. eds. pp 403430. Agronomy Monograph No. 9. Madison, WI: American Society of Agronomy.

Pandey, D. D. and Kumar, S. (1996), Impact of cement dust pollution on biomass, chlorophyll, nutrients and grain characteristics of wheat. Environmental Ecology. 14(4): 872-875.

Pandey, A. K., Dutta, S. and Sharma, K. C. (2005), Environmental degradation due to marble mining dust on the soil quality of Makrana, Nagaur (Raj.). India. Journal of Industrial Pollution Control, 21(1), 139-146.

Rahji, M.A.Y. (2005), Determinants of adoption of soil conservation practices in Oyo State, Nigeria. Moor Journal of Agricultural Research, 6(2), 107114.

Ratcliffe, D. (1974), Ecological effects of mineral exploitation in the United Kingdom and their significance to nature conservation. Royal Security of London Proceedings. Series A. 339: 355-372.

Salahu, B.F. and Dauda, T.O. (2005), Assessing food security status among farming households in Ibadan metropolis, Oyo State, Nigeria. Moor Journal of Agricultural Research, 6(1), 52-59.

Salami, A.T., Farounbi, A.I. and Muoghalu, J.I. (2002), Effects of cement production on vegetation in a part of Southwestern Nigeria. Tanzania Journal of Science. 28(2), 70-82.

Thomas, G.W. (1982), Exchangeable cations. In Methods of Soil Analysis. 2nd ed., Part 2 ed., A. L. Page, R. H. Miller, and D. R. Keeney. eds. pp 159165. Agronomy Monograph No. 9. Madison, WI: American Society of Agronomy.

Wild, A. (1995), Soil and the Environment: An Introduction. Cambridge University Press, Great Britain. 287 pp. 